\title{
Ethno-Linguistic Affiliation and Income Poverty in Native Households with Children: Finland 1987-2011
}

\author{
Camilla Härtull ${ }^{1}$. Jan Saarela ${ }^{1}$
}

Accepted: 26 November 2018 / Published online: 30 November 2018

(c) The Author(s) 2018

\begin{abstract}
The child poverty rate has increased noticeably in Finland since the mid-1990s, and there are numerous studies in this area. However, little is known about child poverty in the two native and equal population groups, Finnish speakers and Swedish speakers. Using detailed register-based data that cover the period 1987-2011, we analyze how child poverty depends on parental ethno-linguistic affiliation, and whether there is variation in income poverty across these households over time. The poverty measure is relative and based on equalized taxable household income of households with children. Odds of poverty are estimated with logistic regression models using generalized estimating equations to account for repeated observations at the household level. The analyses are restricted to areas with both Swedish- and Finnish-speaking settlement. Single-parent and two-parent households are analyzed separately. Poverty rates increased in all major types of households during the study period, but variation by ethno-linguistic affiliation was fairly modest. Swedish-speaking single-parent and two-parent households experienced a smaller increase in the poverty rate than Finnish-speaking ones, while patterns observed for exogamous households were less clear. The contribution of control variables on the ethno-linguistic poverty differences was modest. Considering that the ethno-linguistic groups studied are indigenous and equal, the small differences in poverty rates between Finnish speakers and Swedish speakers are evidence of a democratic and well-functioning welfare state, although the increasing overall poverty rates over time require future scrutiny by both policy makers and researchers.
\end{abstract}

Keywords Income poverty $\cdot$ Households with children $\cdot$ Natives $\cdot$ Ethno-linguistic groups Finland

\section{Introduction}

In an international perspective, the child poverty rate has been low in Finland (Gornick and Jäntti 2012; Natali et al. 2014). Child poverty has nevertheless been a subject undergoing intense discussion in the country during the past two decades, largely caused by

Camilla Härtull

camilla.hartull@abo.fi

1 Faculty of Education and Welfare Studies, Åbo Akademi University, PB 311, 65101 Vaasa, Finland 
the sharp increase in the child poverty rate, starting in the second half of the 1990s. In 1994, during the economic recession, the child poverty rate was at its lowest level ever, or $4.1 \%$. In the following years, Finland recovered from the recession, but the share of children found in poverty started to increase sharply and had in 2007 tripled to $12 \%$. After its peak in 2007, the child poverty rate has decreased slowly, and between 2012 and 2016, which is the most recent official information about child poverty rates available, it has been around 10\% (Statistics Finland 2016). Although child poverty in Finland is quite extensively studied, no research has been concerned with child poverty from the perspective of the two native ethno-linguistic groups, Finnish speakers and Swedish speakers. In this article, we study child poverty from the viewpoint of the household, with these two groups in focus. Due to markedly higher and steeper increase in poverty rates in households with one earner than in those with two earners (see Fig. 1), we analyze single-parent and two-parent households separately. The primary purpose of the article is to find out whether there are differences in income poverty across households that differ on parental ethno-linguistic affiliation, and if there is variation in income poverty across these households over time. Of additional interest is whether any variation in income poverty can be attributed to observable characteristics.

It is widely acknowledged that the well-being of children is depressed if they are living in poverty. Poverty in childhood may also have severe consequences later in life (Bradshaw and Main 2016; Kalil et al. 2016). In Finland, the consequences of child poverty are above all related to the child's social and emotional life. As compared to others, children in families with scarce financial resources are at a greater risk of experiencing limited social relationships, mental illness and even peer discrimination, exclusion and bullying, often because of the stigma of poverty (Haanpää and Roos 2015; Hakovirta and Kallio 2016; Hakovirta and Rantalaiho 2012). Analyzing the causes of child poverty is therefore of utmost importance, and international research on determinants of child poverty is indeed extensive. It is well-established that the likelihood of child poverty is higher in certain types of households, such as in those with a single parent (Bradshaw and Holmes 2010; Chzhen 2014; Gornick and Jäntti 2012; Ottosen and Skov

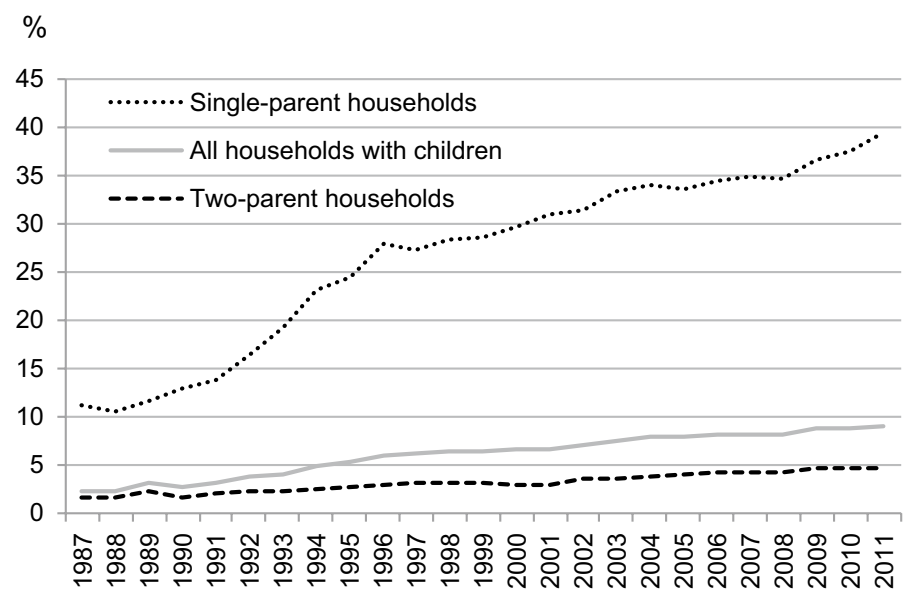

Fig. 1 Poverty rates in households with children in the study region by household type in 1987-2011 (native parents only) 
2013) and in those experiencing unemployment or joblessness (Bradshaw and Holmes 2010; Chzhen 2014; Ottosen and Skov 2013).

Although family structure and parents' attachment to the labour market are considered to be primary determinants of child poverty, it is a complex phenomenon typically explained by a range of factors (Chen and Corak 2008; Salmi et al. 2014), ethnicity being one. Numerous studies show that children in ethnic minorities and immigrant families are overrepresented among the poor (Bradshaw and Holmes 2010; Galloway et al. 2015; Lindquist and Sjögren Lindquist 2012; Ottosen and Skov 2013; Platt 2009). Ethnic minorities are found to be discriminated in the labour market (Booth et al. 2011; Carlsson and Rooth 2007) and immigrants are found to have higher unemployment and lower labour market participation than natives (Bisin et al. 2011). Thus, it has been suggested that also the economic disadvantage of children in these families is related to the weaker labour market situation of their parents (Gábos et al. 2007). Therefore, to understand the interrelation between child poverty and ethnicity, it would be important to know what the outcome would be in the absence of factors that traditionally are related to one group's inferior position. The setting in Finland, with two native and equal population groups, provides an opportunity to overcome the general problems related to studies of this kind (Saarela and Finnäs 2016). We can study the interrelation between child poverty and ethnicity without being concerned with the effects of discrimination, negative attitudes and unsuccessful integration, because Finnish speakers and Swedish speakers are indigenous and similar in most observable respects. They are guaranteed equal constitutional rights and exposed to the same policies, and the society is committed to provide for the cultural and social needs of both groups. These underpinnings make it likely to expect only modest differences in child poverty risks by parental ethno-linguistic affiliation. We study whether this is the case, and whether any differences or variation over time can be explained by differences in observable characteristics.

\section{The Concept and Determinants of Child Poverty}

In this section, we first discuss income-based measurement of child poverty and thereafter present some central studies on the causes of child poverty, all of them using income-based poverty measures. Research on child poverty in Finland is presented in the subsequent section.

Poverty is often defined in either absolute or relative terms. Absolute poverty is based on the notion of subsistence, that is, having enough to sustain life, while relative poverty refers to the lack of resources enabling a decent life in accordance with the rest of the population (Alcock 2006). In academics and policy contexts, poverty is commonly understood as relative to the society in which the individual lives (Main and Bradshaw 2016). This approach is influenced by Townsend (1979) and presumes that living standards are not acceptable under a certain threshold in the income distribution. Although the monetary approach to identify and measure poverty has been criticized, income-based poverty approaches are still the most widely used (Jäntti 2010; Minujin et al. 2006).

Since a child is considered to be poor if it lives in a poor household, child poverty is in practice measured through the income of parents (Jäntti 2010). However, the financial resources available to children are highly dependent on the intra-household distribution of monetary resources (Chzhen et al. 2016). From a child perspective, the assumption that economic resources within the household are equally distributed is questionable, 
because the within-household distribution of these resources can differ between different types of households. Accordingly, children whose parents have equal incomes may themselves have different economic margins (Mood and Jonsson 2016; de Neuborg et al. 2014). Identifying poor children would therefore require data on their actual relative position compared to the adults in the household (Main and Bradshaw 2016). Therefore, in our analyses, we take a somewhat different approach to child poverty and focus on households with children. This is done by using a measure that captures all persons living in the household, that is, the proportion of households with children in poverty (see e.g. Jäntti 2010; OECD 2017).

Child poverty differs from adult poverty in that it may have different causes (Minujin et al. 2006). In Western nations, studies generally point to a strong relationship between child poverty and family structure, and between child poverty and parents' attachment to the labour market. Indisputably, child poverty occurs above all in one-earner families and jobless families. Children in single-parent households are almost inevitably more likely to be found in poverty than children in households with two parents since there is only one earner, whose employment moreover is constrained by caring responsibilities. Although income transfers and support systems help to ease the financial situation for single-parent households, no country has managed to equalize the child poverty rate between singleparent households and two-parent households (Bradbury 2003).

Results from comparisons of child poverty in the United States, Australia, Canada, and several countries in Latin America and Western and Eastern Europe (Gornick and Jäntti 2012; Heuveline and Weinshenker 2008) show that, practically in all countries, poverty rates in single-parent households are notably higher than in two-earner households, and that those headed by a single female are at a greater risk than those headed by a single male. As an example, in the Nordic countries, $3 \%$ of children living in two-earner households, $8 \%$ of children living with their father, and $11 \%$ of the children living with their mother have been found to be poor (Gornick and Jäntti 2012).

In addition to family structure, parents' socioeconomic position and attachment to the labour market are important determinants of child poverty. In virtually all OECD countries, the child poverty risk is higher if neither parent is employed as compared to if one of them is employed (Whiteford and Adema 2007). For example, in the UK, families with neither parent employed where found to be ten times as likely to be poor as families with both parents employed (Bradshaw and Holmes 2010). In Denmark, children whose parent with the family's highest socioeconomic status was outside the labour force were almost 70 times as likely to be found in poverty as compared to those with a parent employed at the highest level (Ottosen and Skov 2013). Results from a study in Sweden show slightly different results (Lindquist and Sjögren Lindquist 2012), as children who had at least one parent suffering from unemployment did not experience an increase in the probability of being poor. This was explained by a well-functioning unemployment insurance system. Longterm unemployment of the parents did increase the probability of child poverty, however.

Household earnings are shaped by the educational level of parents, which therefore affects child poverty risks. The proportion of children living in poverty is found to be higher in families with low-educated parents in Europe, USA, Canada and Latin America (Gornick and Jäntti 2011; Munzi and Smeeding 2006). In the UK, a notable difference in the poverty risk was found between children whose mother's educational level was less than lower tertiary and those whose mother had a tertiary level education (Bradshaw and Holmes 2010). In Denmark, children whose parent with the highest educational level was at the tertiary level were $50 \%$ less likely to be poor than if the parent had a primary education (Ottosen and Skov 2013). In Sweden, children with parents who had completed only 
elementary school were 2-3\% more likely to be poor as compared to those whose parents had high school degrees (Lindquist and Sjögren Lindquist 2012).

Also, the number of children in the family and the size of the household matter. In the UK, the likelihood of being poor was higher if there were two or more children in the household, and the likelihood was increasing by every child (Bradshaw and Holmes 2010; Bradshaw et al. 2006). In Sweden as well, many children in the household implies a higher probability of being poor. Likewise, children living in larger households both in Sweden and in Denmark are more likely to be poor than those living in smaller households (Lindquist and Sjögren Lindquist 2012; Ottosen and Skov 2013).

Studies have also documented a relationship between child poverty and children's age, and between child poverty and parent's age. In the majority of 20 upper-income countries, younger children were more likely to be found in poverty than older ones. This is particularly true in the Nordic countries, where children under the age of 6 years were about $30 \%$ more likely to be poor than children in general (Gornick and Jäntti 2012). This is due to the lower labour market attachment of young children's parents, who are often young themselves and therefore are more likely to be unemployed or hold low-paid jobs as compared to older parents. Additionally, young parents might be less likely to receive some types of social income, such as unemployment and retirement pensions. Also, children with older parents were less likely to be poor than children with young parents in Sweden (Lindquist and Sjögren Lindquist 2012) and in the United Kingdom (Bradshaw and Holmes 2010).

Also marital status is associated with child poverty. In most Western countries, including Finland, child poverty rates are higher in households with cohabiting parents as compared to those with married parents (Bradshaw and Holmes 2010; Heuveline and Weinshenker 2008). However, in Sweden, marital status appears to be less important for the probability of children to be found in poverty (Lindquist and Sjögren Lindquist 2012).

An important dimension of child poverty is the variation across ethnic groups and the reasons for those differences (Galloway et al. 2015; Platt 2009). While child poverty in developed countries has gained extensive interest among researchers and policy makers during the past two decades, the poverty of children from minority groups received much less attention for a long time. However, it is clear that in Western nations, child poverty rates in ethnic minorities are considerably higher than in the majority population. In the UK, over half of the children from the two most disadvantaged groups, Pakistani and Bangladeshi, can expect to be growing up in poverty. Also, children of black ethnicity are at a significantly greater risk of poverty (Bradshaw and Holmes 2010; Platt 2009). In the US, black child poverty rates are highest, followed by the Hispanic (Carson et al. 2017). Also in the Scandinavian countries, which in cross-country comparisons generally have lower child poverty rates than other rich countries (Chen and Corak 2008; Gornick and Jäntti 2012), ethnicity is a strong determinant of child poverty. Ottosen and Skov (2013) found that in Denmark, the odds of being poor is $17 \%$ higher for children whose parents are immigrants, and almost 30\% higher for those who are immigrants themselves, as compared to children of Danish ancestry. In Sweden, being born abroad raises the child's probability of being poor, and it increases additionally if at least one parent was born abroad (Lindquist and Sjögren Lindquist 2012). Galloway et al. (2015) studied immigrant and native child poverty in Sweden, Norway and Denmark in 1993-2001, and found large differences in poverty rates between native children and those with a middle- or low-income country background. While around $8 \%$ of native children in all three countries were found to be poor at the end of the study period, the immigrant child poverty rate was around $55 \%$ in Denmark, somewhat lower in Sweden, and $40 \%$ in Norway. Moreover, the share of poor children with immigrant background clearly increased in all three countries during the 1990s. At the end 
of the study period, one-third of poor children in Norway and about a half in Denmark and in Sweden were of immigrant origin. This development largely reflects the overall labour market situation of immigrants, as there are large difficulties in being employed for those from low- and middle-income countries. Native children in these Scandinavian countries, on the other hand, make up ever smaller proportions of poor children over time.

\section{The Finnish Context}

Also in Finland, having a foreign background increases the risk of being found in child poverty (Jäntti 2010). While the child poverty rate in all children in the country is around $10 \%$, it is estimated to be six times higher among children whose parents are born outside the EU, and every tenth poor child in Finland has an immigrant background. However, the study groups in this article, Finnish speakers and Swedish speakers, constitute a very different setting than the standard immigrant-native comparisons. Finland has had only little immigration until recent years, and for a long time, it was almost unknown for European and global migration streams. Although immigration flows increased in the 1990s, the proportion of persons with a foreign background is considerably lower in Finland as compared to that of other Nordic countries (Helminen 2015).

In Finland, which has a total population of five and a half million persons, the two indigenous population groups, Finnish speakers and Swedish speakers, amount to 88.3 and $5.3 \%$, respectively. The share of persons having some other mother tongue than Finnish or Swedish was until the beginning of the 2000's less than $2 \%$, while they now amount to $6 \%$. Almost all Swedish speakers are settled at the southern and western coastline of Finland, and the internal mobility in the group is low as compared to that of Finnish speakers (Saarela 2006).

The roots of the Swedish-speaking population go far back in time, when Finland was part of Sweden (McRae 1999). Swedish was then the administrative language in Finland, and also the language of the economic, social and cultural elite. The Swedish language maintained its position several decades after 1809, when Finland became part of the Russian Empire. At the end of the 19th century, Finnish achieved the same status as Swedish, and in the Constitution Act of 1919, both languages were given equal status as official languages of the country. As a consequence, the two native population groups have equal constitutional rights, parallel school systems, and they are exposed to the same policies. They are also similar in most observable respects, although they culturally, as defined by group-specific norms, beliefs, preferences, and traditions, differ from each other (Saarela and Finnäs 2016). A number of organizational and institutional networks constitute important elements of the Swedish-speaking society. Besides the school system, there is a Swedish-speaking brigade of the Finnish Army, a diocese for all the Swedish-speaking parishes within the Lutheran Church of Finland, and several Swedish-speaking organizations and societies for, among others, culture, politics, and media (McRae 1999). Intermarriage between Finnish speakers and Swedish speakers is common, although there is a certain degree of asymmetry, since roughly $40 \%$ of the Swedish-speaking men but just over one-third of the Swedish-speaking women marry a Finnish speaker. Approximately $60 \%$ of all new-born children in intermarried families are registered as Swedish speakers (Finnäs 2013).

A general belief, probably derived from times when Swedish speakers dominated the upper class, is that they are overrepresented among those well-to-do. To some extent this 
is found to be true. Swedish speakers are higher educated and live longer than Finnish speakers (Saarela and Finnäs 2003, 2006, 2010). Their unemployment rates are lower and wealth levels on average higher than those of Finnish speakers (Saarela 2004, 2006). In the Helsinki metropolitan area, Swedish-speaking men earn more than Finnish-speaking men, which is foremost because of higher education and age (Saarela and Finnäs 2004). However, there is considerable regional variation in the distribution of high income across the two population groups, and in some areas the situation is even the opposite, meaning that Finnish speakers have higher income than Swedish speakers (Saarela 2004). Hence, even though the Swedish-speaking population in Finland constitute a minority in number, it is not an underprivileged group. But whereas quite many studies have focused on differences in wealth and income between Finnish and Swedish speakers, less is known about variation in poverty across the two groups. One study on this topic was concerned with social assistance receipt in a local labour market, the city of Vaasa, in 1993 (Saarela 2002). It found that the probability of receiving social assistance, which is a rough proxy for low income, was notably higher among Finnish speakers than among Swedish speakers. Another study showed that although Swedish speakers had a higher propensity for having low income at the end of the 1990s, their relative position as compared to the Finnish speakers improved during that decade (Härtull and Saarela 2014). Results from a study that focused on income mobility and permanent poverty in Finland 1995-2008, indicated that short-time and longtime poverty rates were lower in the Swedish-speaking population than in the Finnishspeaking one (Riihelä and Suoniemi 2015). Whether findings from these studies can be generalized to households with children in areas with Swedish-speaking settlement is not clear, though.

The causes of poverty in families with children in Finland are multi-dimensional, but one of the most important determinants is family structure. A notable share of poor children lives in single-parent households, and households with three or more children are at a significantly greater risk than those with one or two children (Härtull et al. 2017; Salmi et al. 2014). Parental non-employment also increases the probability of child poverty. In 2007, half of the poor families with children had no family member employed (Salmi et al. 2012). In the 1990s and 2000s, the poverty rates were notably higher in households with parents being unemployed or outside the labour force as compared to those with parents in employment (Härtull et al. 2017). However, poverty occurs also in families with employed parents. In poor families, low-paid work and atypical employment such as part-time work and short fixed-term contracts is more common than in non-poor families, which is due to shorter education of parents in the poor families (Salmi et al. 2012, 2014). Children whose parents had no education after elementary school were four times as likely to be poor as compared to those whose parents had a tertiary level education (Härtull et al. 2017; Salmi et al. 2009). Families with children under 3 years of age, and families with teenagers, were also at a greater risk of being found in poverty than were those with children between 7 and 12 years of age (Gornick and Jäntti 2011; Salmi et al. 2014).

While much is known about the determinants of child poverty in Finland, and it is clear that child poverty rates have varied a lot during the past three decades, it is not known whether there are differences in income poverty between Finnish-speaking and Swedishspeaking households with children. The purpose of this article is therefore to study how child poverty depends on parental ethno-linguistic affiliation, and whether there has been variation in income poverty across these households over the study period 1987-2011. Of additional interest is to see whether any variation can be attributed to area of residence and other observable characteristics. Since the groups studied are native and equal, and we therefore do not need to be concerned with effects of discrimination and other intervening 
factors related to one group's inferior position, we expect the differences in the odds of poverty by parental ethno-linguistic affiliation to be modest.

\section{Data and Methods}

The study is based on data (permission TK-53-768-12) from the Finnish population register, with linkage to Statistics Finland's employment statistics file. Since the Finnish population register include data on the unique mother tongue of every citizen, we can separate Swedish speakers and Finnish speakers. The data consist of a 20\% random sample of all persons with Swedish as their native language, and a 5\% random sample of all persons with a native language other than Swedish, who lived in Finland during any of the years 1987-2011. All index persons can be observed at any of these years if they lived in the country. Persons living in the same household have the same unique household code, and therefore each index person can be linked to the potential partner and to the children. The size of each household and the age of each person living in it are known. On basis of the random sample of index persons, it is therefore possible to construct households and focus on those with children. To adjust for the oversampling of Swedish speakers, weights are used in the analyses.

Based on recommendations from the EU, a child is considered to be at risk of poverty if it lives in a household whose equivalized income is under the poverty threshold, which in the EU usually is $60 \%$ of the median equivalised disposable income (Eurostat 2017). Measuring poverty in households with children, which we do in this paper, means that all persons living in the household are accounted for. Thus, we measure whether households with children are poor, instead of whether children are poor (see also Jäntti 2010 and OECD 2017). We use a relative poverty line, which in this study is set at $60 \%$ of the median equivalized taxable income. Disposable income, or any other alternative for measuring household resources, was not available from the data. Equivalized taxable household income is obtained by summing the taxable income of each person in the household and using the modified OECD equivalence scale. The income of each person is known since taxation in Finland is at the individual level. Taxable income refers to income from earnings, self-employment and capital. A similar measure has been used in studies of child poverty in Finland (Härtull et al. 2017) and in Sweden (Lindquist and Sjögren Lindquist 2012). Income from each year in the data has been adjusted for inflation into 2013 year's prices using the consumer price index.

The analyses are restricted to areas with both Swedish- and Finnish-speaking settlement. Since we study poverty in native households, only those whose parents are Finnish or Swedish speakers are included in the analyses. The focus is on how income poverty is related to parental ethno-linguistic affiliation, and therefore, extended families such as those including grandparents, are not included in the analyses. The descriptive statistics show that just above $10 \%$ of both single-parent and two-parent households are Swedishspeaking (Table 1). In two-parent households, endogamous Finnish-speaking households make up $80 \%$ and exogamous households $9 \%$ of the households.

Since poverty rates were markedly higher in single- than in two-parent households (Fig. 1), and the increase in poverty rates was much greater in households with only one parent, single-parent and two-parent households are analyzed separately. In two-parent households, the poverty rate increased from 2 to almost $5 \%$ during the study period, while in single-parent households it increased from 11 to almost $40 \%$. 
Table 1 Distribution of explanatory variables in single-parent and two-parent households, all years (\%)

\begin{tabular}{lrlr}
\hline Single-parent households & Two-parent households \\
\hline Parent's ethno-linguistic affiliation & & Parents' ethno-linguistic composition \\
Finnish-speaking & 89.8 & Endogamous Finnish-speaking & 80.5 \\
Swedish-speaking & 10.2 & Endogamous Swedish-speaking & 11.0 \\
& 100.0 & Exogamous & 8.6 \\
& & & 100.0
\end{tabular}

\section{Labour market status}

Employed

Unemployed

Outside the labour force

Children $<$ three years in the household

No

Yes

Children $<18$ years in the household

One

Two

Three and $>$

Children 18 years or more in the household

No

Yes

Parent's age

$<36$ years

36-45 years

46 years and $>$

\section{Joint labour market status}

75.5 Both employed $\quad 76.1$

10.0 Man employed, woman unemployed 3.1

14.5 Man employed, woman outside the labour $\quad 12.0$ force

100.0 Man unemployed, woman employed 2.9

Both unemployed 0.5

Man unemployed, woman outside the labour $\quad 0.9$ force

Man outside the labour force, woman employed

Man outside the labour force, woman unemployed

Both outside the labour force

100.0

Children $<$ three years in the household

$86.1 \mathrm{No}$

70.0

13.9 Yes

30.0

100.0

100.0

Children $<18$ years in the household

61.8 One

42.4

29.2 Two

41.5

9.0 Three and $>\quad 16.1$

100.0

100.0

Children 18 years or more in the household

$89.5 \mathrm{No}$

10.5 Yes

100.0

100.0

30.5

$32.3<36$ years

$46.2 \quad 36-45$ years

24.5

21.546 years and $>$

100.0

Woman's age

$<36$ years

36-45 years

44.9

46 years and $>$ 
Table 1 (continued)

\begin{tabular}{|c|c|c|c|}
\hline Single-parent households & & Two-parent households & \\
\hline Parent's sex & & Marital status & \\
\hline Male & 10.9 & Married & 83.6 \\
\hline \multirow[t]{7}{*}{ Female } & 89.1 & Cohabiting & 16.4 \\
\hline & 100.0 & & 100.0 \\
\hline & & Woman's share of couple's income & \\
\hline & & $0-30 \%$ & 27.9 \\
\hline & & $31-50 \%$ & 50.5 \\
\hline & & $>50 \%$ & 21.6 \\
\hline & & & 100.0 \\
\hline Parent's education & & Parents' joint education & \\
\hline Primary & 29.5 & Both primary & 8.1 \\
\hline Secondary & 39.2 & Man primary, woman secondary & 8.6 \\
\hline \multirow[t]{8}{*}{ Tertiary } & 31.3 & Man primary, woman tertiary & 4.4 \\
\hline & 100.0 & Man secondary, woman primary & 7.6 \\
\hline & & Both secondary & 16.3 \\
\hline & & Man secondary, woman tertiary & 12.9 \\
\hline & & Man tertiary, woman primary & 2.8 \\
\hline & & Man tertiary, woman secondary & 9.7 \\
\hline & & Both tertiary & 29.6 \\
\hline & & & 100.0 \\
\hline Municipality of residence & & Municipality of residence & \\
\hline Helsinki & 33.6 & Helsinki & 22.9 \\
\hline Vantaa & 12.2 & Vantaa & 11.5 \\
\hline Espoo-Kauniainen & 12.9 & Espoo-Kauniainen & 13.7 \\
\hline Uusimaa & 13.6 & Uusimaa & 16.9 \\
\hline Western Uusimaa & 4.1 & Western Uusimaa & 5.2 \\
\hline P orvoo-Sipoo & 2.6 & Porvoo-Sipoo & 4.1 \\
\hline Eastern Uusimaa & 1.2 & Eastern Uusimaa & 1.4 \\
\hline Turku & 10.1 & Turku & 7.8 \\
\hline Turunmaa & 2.0 & Turunmaa & 3.3 \\
\hline Vaasa & 2.9 & Vaasa & 3.2 \\
\hline Rural area south of Vaasa & 0.8 & Rural area south of Vaasa & 1.8 \\
\hline Rural area north of Vaasa & 1.3 & Rural area north of Vaasa & 3.9 \\
\hline Pietarsaari & 0.8 & Pietarsaari & 1.2 \\
\hline \multirow[t]{2}{*}{ Kokkola } & 1.9 & Kokkola & 3.0 \\
\hline & 100.0 & & 100.0 \\
\hline
\end{tabular}

The joint variable ethno-linguistic background $x$ year is not shown

Logistic regression models are used to estimate the odds of being categorized as poor. All analyses are at the household level. To see whether and how estimates for parental ethno-linguistic affiliation and other determinants of poverty differ in size, we estimate models for single-parent households and two-parent households, respectively, with joint effects of ethno-linguistic background and year, and main effects of control variables. In a statistical sense, that is identical to adding interaction effects of 
ethno-linguistic background and year to the model that includes main effects (Saarela and Finnäs 2014). Since each household may be repeatedly observed over the calendar years, the logistic regression models are specified with generalized estimating equations (Wang 2014). The technique corrects for within-subject correlations and thus accounts for the dependency of observations that belong to the same household (Liang and Zeger 1986; Zeger and Liang 1986).

The explanatory variable in focus in single-parent households is the parent's mother tongue, which separates Finnish speakers from Swedish speakers. In two-parent households, the explanatory variable in focus is the ethno-linguistic composition of the household according to each parent's mother tongue, that is, Finnish or Swedish. This variable has three categories: endogamous Finnish-speaking households, endogamous Swedishspeaking households, and exogamous households. Control variables used are parents' labour market status, their educational level and age, whether there are children under 3 years, or children who have turned 18 years in the household, the number of children under 18 years, the sex of the parent (in single-parent households), and area of residence. In two-parent households, labour market status is replaced by parents' joint labour market status, and education by their joint education. Joint labour market status refers to the contemporary labour market status held by each parent, and joint education to the contemporary highest educational level held by each parent. The approach with joint effects is equal to adding interaction effects of man's and woman's labour market status, or education, to the model that includes main effects (Saarela and Finnäs 2014). Two-parent households are additionally controlled for marital status and the woman's share of the couple's income.

The control variables are categorized as follows. Labour market status separates persons being employed from those being unemployed or outside the labour force as measured at the last week of each calendar year. The variable has three categories since persons who are not employed or unemployed are found outside the labour force. Among those in working ages, persons outside the labour force mainly consist of parents taking care of their children at home, students, disabled, and persons suffering from long-term illness. Age separates parents under 36 years from those aged 36-45 years, and those over the age of 45 years. That categorization is similar to the one used in previous research on ethno-linguistic income variation in Finland (Härtull and Saarela 2018) and was also in this study found to be appropriate. Education is categorized into primary, secondary, and tertiary level, as has been done in studies of education in the ethno-linguistic groups in Finland (O'Leary and Finnäs 2002; Saarela and Finnäs 2014). We control for whether there are children under 3 years in the household since households with children under that age are known to be overrepresented among those on low income (Salmi et al. 2014). The number of minor children in the household separates households with one child from those with two children or more than two children. We also control for whether there are children that have turned 18 in the household, because although they are no longer minor, they may still be cared for by their parents. Marital status distinguishes between married and cohabiting couples. Divorced parents living as sole-providers are analyzed as single-parent households, but if they are re-married or re-cohabiting, they are analyzed as two-parent households. Woman's share of couple's income consists of the categories $0-30 \%, 31-50 \%$, and more than 50\%. Area of residence distinguishes between 14 areas, which were formed of the 39 original municipalities. Cities formed their own areas. Smaller towns and rural municipalities were primarily grouped based on geographical position, but also on the population structure, that is, the share of Swedish speakers.

The estimates for effects of the control variables are presented in Table 2 . The number of households analyzed is on average 25,000 per year. 


\section{Results}

Poverty rates by parental ethno-linguistic affiliation are presented in Fig. 2, in which the upper graph (a) refers to single-parent households and the lower graph (b) to two-parent households. The results of the logistic regression analyses, specified with generalized estimating equations, for single-parent households are summarized in Fig. 3, and those for twoparent households in Figs. 4 and 5. Graph (a) in each of these figures summarizes the unadjusted odds ratios for each year. In graph (b), the results are adjusted for all control variables except area of residence, and in graph (c), area of residence is additionally controlled for.

In spite of a large increase in the poverty rates over time, the differences between ethnolinguistic groups were fairly modest (Fig. 2). Swedish-speaking single-parent households were at a higher level in the late 1980s, but experienced a smaller increase in the poverty rate than Finnish-speaking single-parent households, and were in 2011 less likely to be found in poverty (Graph (a) in Fig. 2). In two-parent households, the poverty rate was highest in endogamous Swedish-speaking households at the end of the 1980s. However, they experienced a smaller increase than other households, from 3.0 to $4.6 \%$, during the study period (Graph (b) in Fig. 2), and were in 2011 as likely to be found in poverty as households with endogamous Finnish-speaking parents. The lowest poverty rate at the beginning and at the end of the study period was found in exogamous households.

The results of the logistic regressions show that whereas Swedish-speaking single- and two-parent households experienced a fairly monotonous decrease in the relative probability of being found in poverty as compared to Finnish-speaking households, the trend for the relative position in exogamous households is less clear. In single-parent households, the odds ratio of poverty between Swedish-speaking and Finnish-speaking households decreased from 1.3 in 1987 to 0.8 in 2011 (Graph (a) in Fig. 3). In two-parent households, endogamous Swedish-speaking households were 1.5 times as likely to be found in poverty as compared to endogamous Finnish-speaking households in 1987, while at the end of the study period the odds ratio had decreased to 0.7 (Graph (a) in Fig. 4). The odds ratio of poverty between exogamous households and endogamous Finnish-speaking households was around one throughout the study period (Graph (a) in Fig. 5).

In single-parent households, control variables had a fairly modest effect on the difference in the odds of poverty by parental ethno-linguistic affiliation. The difference between Swedish-speaking and Finnish-speaking households increased slightly when we controlled for other observable characteristics except for area of residence (Graph (b) in Fig. 3), while area of residence had no additional effect (Graph (c) in Fig. 3). In two-parent households, a similar pattern could be observed for the difference between endogamous Swedish-speaking and endogamous Finnish-speaking households when we adjusted for control variables except for area of residence (Graph (b) in Fig. 4). This difference decreased somewhat when we additionally controlled for area of residence (Graph (c) in Fig. 4). The contribution of control variables to the difference in the odds of poverty between exogamous households and endogamous Finnish-speaking households was negligible (Graph (b) and Graph (c) in Fig. 5).

The estimates for all control variables (Table 2) show that poverty is more likely to be found in households with non-employed parents as compared to those with employed parents. In the non-employed households, those whose parents are outside the labour force are at a noticeably greater risk than those whose are unemployed. The risk is also higher in households with low parental education and in households with younger parents. In households with at least two children, the odds of poverty are larger than in those with one child. Having children under the age of three implies a higher risk of poverty only in 
single-parent households, while having children older than 17 years implies a lower risk in two-parent households. In single-parent households headed by a woman, the odds of poverty are higher than in those headed by a man. In two-parent households, non-married are more likely to be found in poverty than married. If the woman earns more than half of the couple's income, the household is at a greater risk as well. The odds of poverty are larger in the cities of Turku and Kokkola, and in the rural areas south of Vaasa, than in Helsinki. The only significant lower risk of poverty, as compared to Helsinki, is found in two-parent households in the city of Vantaa.

\section{Discussion}

During the past two decades, the proportion of children living in poverty has increased in Finland and many other Western countries, and the phenomenon has gained a great deal of interest among researchers. Recent years, the considerable variation in child poverty rates across ethnic groups has also been an issue of concern. This paper contributes to the existing literature on child poverty and ethnicity by studying whether and how culturally different but otherwise similar and equal ethno-linguistic groups differ in terms of child poverty. In this article, we have focused on the two native population groups in Finland, Finnish speakers and Swedish speakers. Using annual microdata representing the period 1987-2011, and a relative poverty measure that captures all persons living in the household, we have studied child poverty by comparing households that differ on parents' mother tongue. Of particular interest has been whether there is variation in income poverty across these households over time. We also attempted to see whether any variation in poverty across these households can be attributed to observable characteristics.

The results show that, although poverty rates increased in all major types of households between 1987 and 2011, the variation over time by ethno-linguistic affiliation was fairly modest. In single-parent households, the poverty rate increased less in those with a Swedish-speaking parent than in those with a Finnish-speaking one, and at the end of the study period, they were less likely to be found in poverty. Endogamous Swedish-speaking twoparent households also experienced a smaller increase in the poverty rate as compared to other two-parent households. Thus, Swedish-speaking families with children seem to have improved their relative position at the lower end of the income distribution. This development was particularly noticeable before the 2000's and is consistent with results from previous research on ethno-linguistic differences in low-income earning based on individual data (Härtull and Saarela 2014). The relative pattern we found for exogamous two-parent households is less clear, indicating that they lie more or less at parity with endogamous Finnish-speaking households.

Within single-parent households, the difference in the odds of poverty by parent's ethno-linguistic affiliation could not be attributed to the area of residence, while controls for other individual and household characteristics increased the likelihood slightly. A similar pattern could be observed within endogamous two-parent households. However, the difference between endogamous Swedish-speaking and endogamous Finnish-speaking households was to some extent explained by differences in the area of residence. Until the mid-1990s, income inequality between urban and rural areas, and between the metropolitan area and other regions, decreased clearly in Finland (Loikkanen et al. 1998, 2000). Since areas with high rates of Swedish speakers to a large extent are rural, that development consequently seems to have benefitted the Swedish speakers. Accordingly, since single-parenthood is less common in rural areas than in urban (Table 1), area of residence did not have 


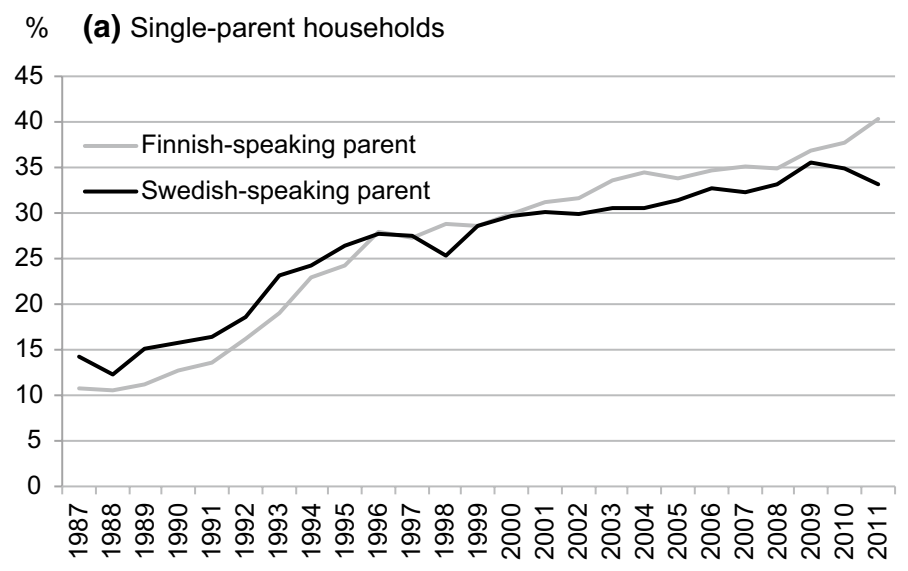

$\%$ (b) Two-parent households

6

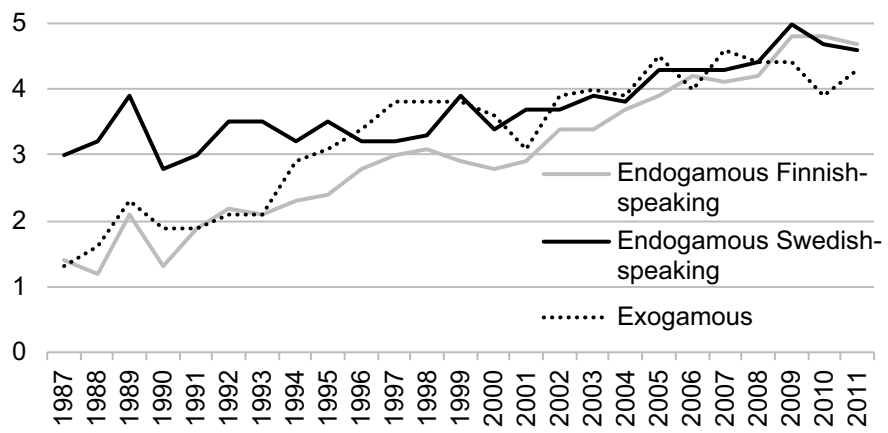

Fig. 2 Poverty rates in households with children by parents' ethno-linguistic affiliation, in 1987-2011

any effect on the poverty differences by parental ethno-linguistic affiliation in single-parent households in our analyses.

It should be emphasized that, although there seems to be a trend in favor of Swedish-speaking single-parent households and endogamous Swedish-speaking two-parent households, the difference in the poverty rate by ethno-linguistic background is fairly small. It needs to be stressed as well that Swedish-speaking households were more likely to be found in poverty than Finnish-speaking households throughout the major part of the study period, even when we controlled for individual and household characteristics. The reasons are not clear, but might be associated with ethno-linguistic differences in the propensity to move. Since internal mobility in Finland is lower in the Swedish-speaking population than in the Finnish-speaking, Swedish-speaking households with children are probably also less likely to move because of job offers that would lift them out of poverty, as compared to their Finnish-speaking counterparts.

A limitation of this study is that disposable income was not available from the data used, and measuring poverty as is done by Statistics Finland, for example, was therefore not possible. Measuring poverty based on taxable income, which we did, implies that the measure does not include non-taxable income transfers such as housing allowance and social assistance, which are means tested and presumably important incomes for low-income households. The 


\section{Odds ratio (a)}

\section{5}

2.0

1.5

1.0

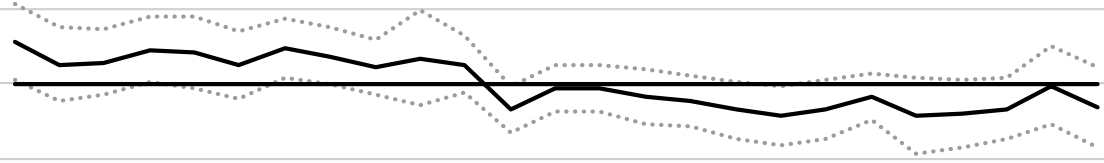

0.5

0.0

ר.

\section{Odds ratio (b)}

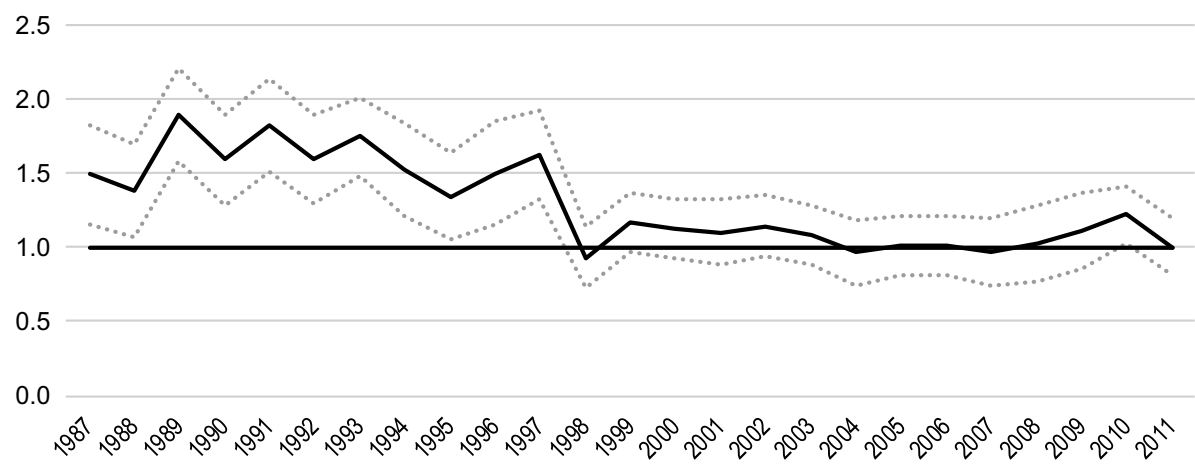

Odds ratio (c)

2.5

2.0

1.5

1.0

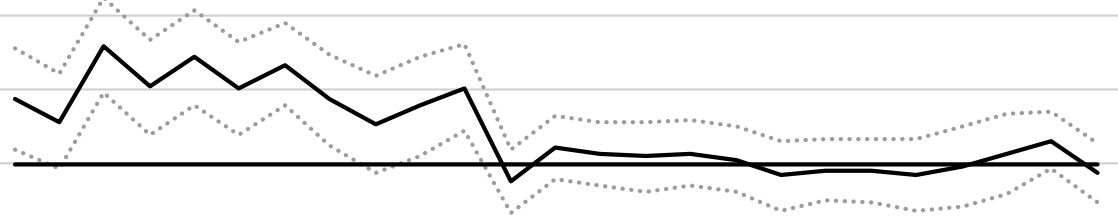

0.5

0.0

م

Fig. 3 Odds ratios of poverty between Swedish-speaking and Finnish-speaking (reference, set to 1) singleparent households, 1987-2011. Notes: a Unadjusted odds ratio. b Odds ratio adjusted for all control variables except area of residence. $\mathbf{c}$ Odds ratio adjusted for all control variables. All odds ratios are estimated with $95 \%$ confidence intervals

use of taxable income also implies that the re-distributional effects of taxation of income are not taken into account. Households at the lower end might therefore have access to higher income than our data indicate. However, there are to our knowledge no other data suitable 


\section{Odds ratio (a)}

$$
3.0
$$

2.5

2.0

1.5

A

1.0

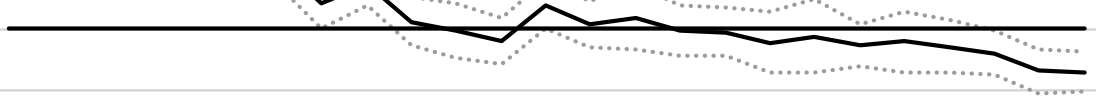

0.5

0.0

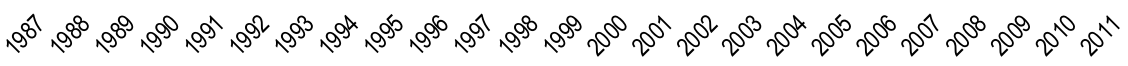

\section{Odds ratio (b)}

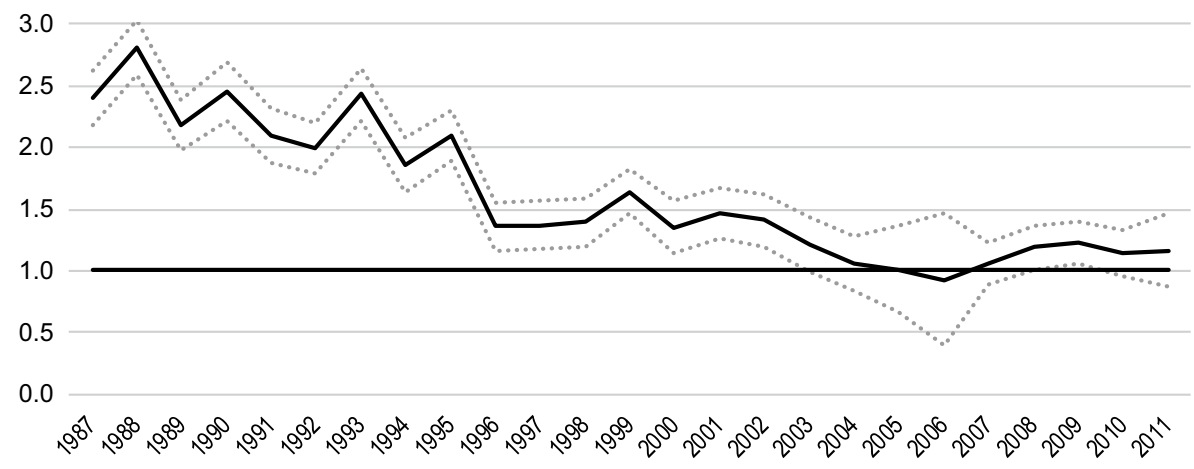

Odds ratio (c)

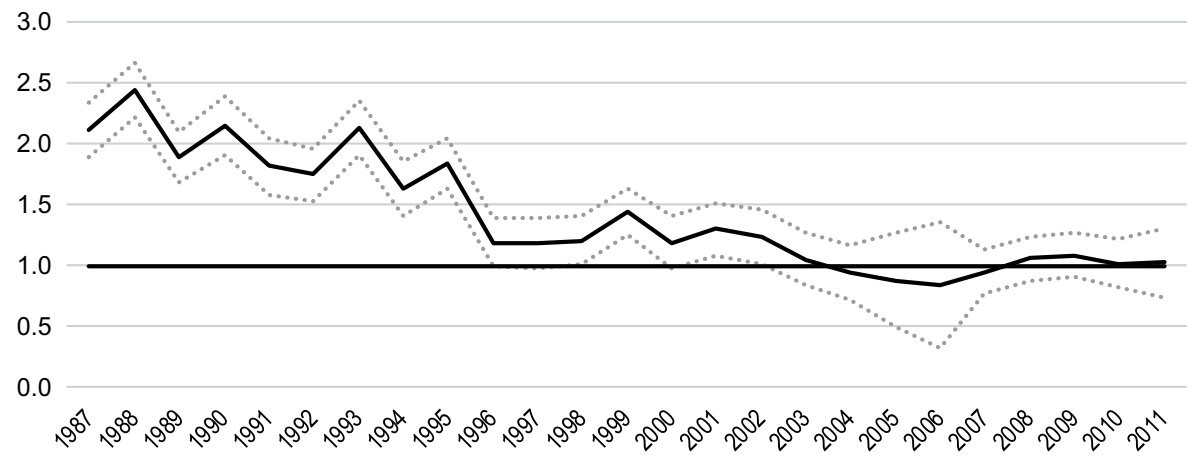

Fig. 4 Odds ratios of poverty between endogamous Swedish-speaking and endogamous Finnish-speaking (reference, set to 1) two-parent households, 1987-2011. Notes: a Unadjusted odds ratio. b Odds ratio adjusted for all control variables except area of residence. c Odds ratio adjusted for all control variables. All odds ratios are estimated with $95 \%$ confidence intervals

for comparing the ethno-linguistic groups with regard to income poverty. This calls for developing the official statistics in order to enable studies on ethno-linguistic poverty differences based on disposable income, which also is our suggestion for future research. 


\section{Odds ratio (a)}

3.0

2.5

2.0

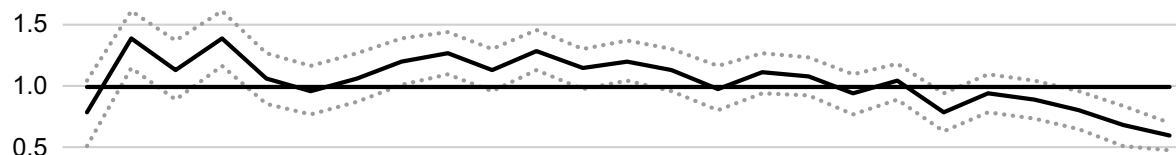

0.0

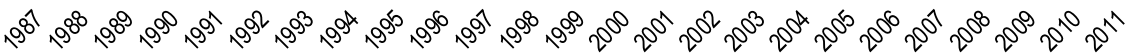

Odds ratio

(b)

3.0

2.5

2.0

1.5

1.0

0.5

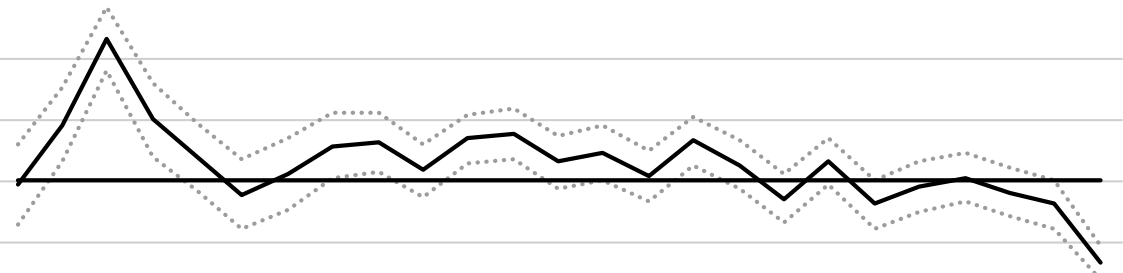

0.0

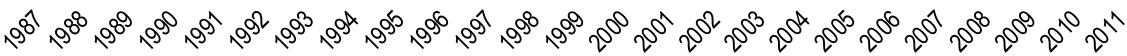

Odds ratio

(c)

3.0

2.5

2.0

1.5

1.0

0.5

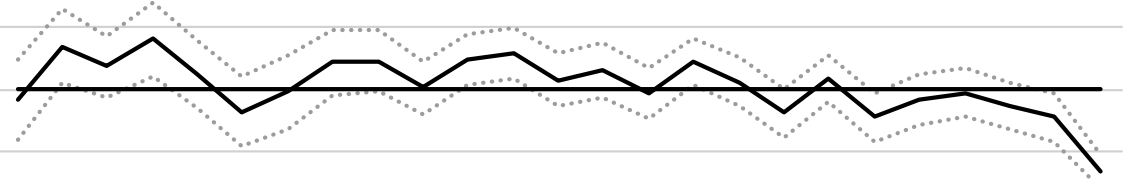

0.0

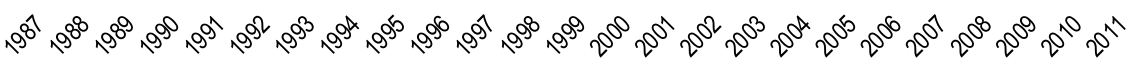

Fig. 5 Odds ratios of poverty between exogamous and endogamous Finnish-speaking (reference, set to 1) two-parent households, 1987-2011. Notes: a Unadjusted odds ratio. b Odds ratio adjusted for all control variables except area of residence. c Odds ratio adjusted for all control variables. All odds ratios are estimated with $95 \%$ confidence intervals

In this article, we have shown that when groups are native and stand on equal ground, the ethno-linguistic affiliation of the parents has a modest bearing on the risk of households with children to be found in income poverty. During the study period, no language acts or other reforms that would have worsened one ethno-linguistic group's relative position, as compared to 
the other, were undertaken. The small variation in poverty rates across households that differ on ethno-linguistic affiliation in Finland can therefore be seen as evidence in favor of a well-functioning and democratic welfare state, in which both ethno-linguistic groups are offered equality in outcome and protection by language acts and constitutional rights. However, a policy implication arises from the markedly increasing overall poverty rates over time. They would require urgent scrutiny by policy not least because of the severe consequences poverty may have on the well-being of children and their chances in future life. Policies specifically directed towards households at risk of being marginalized, such as those with low-educated parents and those with parents outside the labour force, therefore seem utmost needed.

In Finland, both Finnish and Swedish are mandatory subjects for pupils in primary and secondary schools, but the language climate in the country has hardened in recent years. As an example, in 2015, a citizens' initiative called for an end to the compulsory teaching of Swedish in Finnish-speaking schools (Yle 2015). It was voted against by the parliament, but only 2 years later, a so-called language experiment was approved by the parliament (Ministry of Education and Culture 2017). It was planned to start in 2018 and give some 2000 pupils the option to choose, whether they want to study some other language instead of the official language that is not their mother tongue. However, due to little interest by the municipalities that were chosen for the experiment, it was not carried out. If the experiment would have been realized, the interest to learn Swedish in the Finnish-speaking population might have declined. As a consequence, the status of Swedish as an official language, and the equal position of the Swedish-speaking population, as compared to the Finnishspeaking one, might, in the long run, have been threatened and their situation become more alike the one of other ethnic minorities, with higher child poverty rates as compared to the majority population. Their improved relative position, which is seen in the results of this paper, might in such a case not be maintained in the long term. Ensuring that the other official language of the country is learned by both ethno-linguistic groups is therefore in accordance also with the European Commission's language policy, which promotes language learning and linguistic diversity.

Acknowledgements Open access funding provided by Abo Akademi University (ABO). Financial support from Högskolestiftelsen i Österbotten and Svenska Litteratursällskapet i Finland is gratefully acknowledged.

\section{Compliance with Ethical Standards}

Conflict of interest The authors declare that they have no conflict of interest.

Open Access This article is distributed under the terms of the Creative Commons Attribution 4.0 International License (http://creativecommons.org/licenses/by/4.0/), which permits unrestricted use, distribution, and reproduction in any medium, provided you give appropriate credit to the original author(s) and the source, provide a link to the Creative Commons license, and indicate if changes were made.

\section{Appendix}

See Table 2. 
Table 2 Odds ratios of income poverty (estimates for control variables)

\begin{tabular}{|c|c|c|c|}
\hline Single-parent households & & Two-parent households & \\
\hline Labour market status & & Joint labour market status & \\
\hline Employed & 1 & Both employed & 1 \\
\hline Unemployed & $12.08 *$ & Man employed, woman unemployed & $3.68 *$ \\
\hline \multirow[t]{7}{*}{ Outside the labour force } & $18.17 *$ & Man employed, woman outside the labour force & $6.28 *$ \\
\hline & & Man unemployed, woman employed & $2.53^{*}$ \\
\hline & & Both unemployed & $15.40^{*}$ \\
\hline & & Man unemployed, woman outside the labour force & $26.52 *$ \\
\hline & & Man outside the labour force, woman employed & $5.14^{*}$ \\
\hline & & Man outside the labour force, woman unemployed & $24.50 *$ \\
\hline & & Both outside the labour force & $59.33^{*}$ \\
\hline Children $<$ three years in the $h h$ & & Children $<$ three years in the $h h$ & \\
\hline No & & No & 1 \\
\hline Yes & $1.73^{*}$ & Yes & 0.92 \\
\hline Children $<18$ years in the $h h$ & & Children $<18$ years in the $h h$ & \\
\hline One & & One & 1 \\
\hline Two & $1.96^{*}$ & Two & $1.31^{*}$ \\
\hline Three and $>$ & $5.13^{*}$ & Three and $>$ & $2.45^{*}$ \\
\hline Children 18 years or more in the hh & & Children 18 years or more in the hh & \\
\hline No & 1 & No & 1 \\
\hline Yes & 1.11 & Yes & $0.85 *$ \\
\hline Parent's age & & Man's age & \\
\hline$<36$ years & $2.54^{*}$ & $<36$ years & $1.40^{*}$ \\
\hline $36-45$ years & $1.45^{*}$ & $36-45$ years & 1.09 \\
\hline \multirow[t]{5}{*}{46 years and $>$} & 1 & 46 years and $>$ & 1 \\
\hline & & Woman's age & \\
\hline & & $<36$ years & $1.59 *$ \\
\hline & & $36-45$ years & $1.35^{*}$ \\
\hline & & 46 years and $>$ & 1 \\
\hline Parent's sex & & Marital status & \\
\hline Male & 1 & Married & 1 \\
\hline \multirow[t]{5}{*}{ Female } & $1.42 *$ & Cohabiting & $1.19^{*}$ \\
\hline & & Woman's share of couple's income & \\
\hline & & $0-30 \%$ & $0.77 *$ \\
\hline & & $31-50 \%$ & 1 \\
\hline & & $>50 \%$ & $3.00^{*}$ \\
\hline Parent's education & & Parents' joint education & \\
\hline Primary & $3.64 *$ & Both primary & $5.02 *$ \\
\hline Secondary & $2.46^{*}$ & Man primary, woman secondary & $2.83^{*}$ \\
\hline \multirow[t]{6}{*}{ Tertiary } & 1 & Man primary, woman tertiary & $1.29^{*}$ \\
\hline & & Man secondary, woman primary & $3.15^{*}$ \\
\hline & & Both secondary & $2.32 *$ \\
\hline & & Man secondary, woman tertiary & 1.11 \\
\hline & & Man tertiary, woman primary & $2.26^{*}$ \\
\hline & & Man tertiary, woman secondary & $1.85^{*}$ \\
\hline
\end{tabular}


Table 2 (continued)

\begin{tabular}{llll}
\hline Single-parent households & \multicolumn{3}{c}{ Two-parent households } \\
\hline Area of residence & \multicolumn{3}{l}{ Both tertiary } \\
Helsinki & \multicolumn{1}{l}{ Area of residence } & 1 \\
Vantaa & 0.91 & Velsinki & 1 \\
Espoo-Kauniainen & 0.83 & Espoo-Kauniainen & $0.82^{*}$ \\
Uusimaa & 1.11 & Uusimaa & 0.97 \\
Western Uusimaa & 1.04 & Western Uusimaa & 1.04 \\
P orvoo-Sipoo & 1.00 & Porvoo-Sipoo & $1.26^{*}$ \\
Eastern Uusimaa & 0.94 & Eastern Uusimaa & 1.03 \\
Turku & $1.15^{*}$ & Turku & $1.70^{*}$ \\
Turunmaa & 1.00 & Turunmaa & $1.16^{*}$ \\
Vaasa & $1.40^{*}$ & Vaasa & $1.27^{*}$ \\
Rural area south of Vaasa & $1.46^{*}$ & Rural area south of Vaasa & 1.13 \\
Rural area north of Vaasa & 1.19 & Rural area north of Vaasa & $1.28^{*}$ \\
Pietarsaari & $1.81^{*}$ & Pietarsaari & $1.27^{*}$ \\
Kokkola & $1.68^{*}$ & Kokkola & 0.86 \\
\hline
\end{tabular}

$* p<0.05$

\section{References}

Alcock, P. (2006). Understanding poverty (3rd ed.). Basingstoke: Palgrave Macmillan.

Bisin, A., Patacchini, E., Verdier, T., \& Zenou, Y. (2011). Ethnic identity and labour market outcomes of immigrants in Europe. Economic Policy, 26(65), 57-92.

Booth, A. L., Leigh, A., \& Varganova, E. (2011). Does ethnic discrimination vary across minority groups? Evidence from a field experiment. Oxford Bulletin of Economics and Statistics, 74(4), 547-573.

Bradbury, B. (2003). Child poverty: A review. Policy Research Paper, No 20. Australia Commonwealth Department of Family and Community Services.

Bradshaw, J., Finch, N., Mayhew, E., Ritakallio, V.M., \& Skinner, C. (2006). Child poverty in large families. Research Report. Bristol: Policy Press.

Bradshaw, J., \& Holmes, J. (2010). Child poverty in the first five years of life. In K. Hansen, H. Joshi, \& S. Dex (Eds.), Children of the 21st century: The first five years (pp. 13-32). Bristol: The Policy Press.

Bradshaw, J., \& Main, G. (2016). Child poverty and deprivation. In J. Bradshaw (Ed.), The Wellbeing of Children in the UK (pp. 31-70). Bristol: Policy Press at the University of Bristol.

Carlsson, M., \& Rooth, D.-O. (2007). Evidence of ethnic discrimination in the Swedish labor market using experimental data. Labour Economics, 14(4), 716-729.

Carson, J., Mattingly, M., \& Schaefer, A. (2017). Gains in Reducing Child Poverty, but Racial-Ethnic Disparities Persist. Carsey Research, National Issue Brief No. 118.

Chen, W. H., \& Corak, M. (2008). Child poverty and changes in child poverty. Demography, 45(3), 537-553.

Chzhen, Y. (2014). Child poverty and material deprivation in the European Union during the Great Recession. Innocenti Working Papers No 2014-06. UNICEF Office of Research Working Paper.

Chzhen, Y., de Neubourg, C., Plavgo, I., \& de Milliano, M. (2016). Child poverty in the European Union: the multiple overlapping deprivation analysis approach (EU-MODA). Child Indicators Research, 9(2), 335-336. https://doi.org/10.1007/s12187-015-9321-7.

De Neuborg, C., De Milliano, M., \& Plavgo, I. (2014). Lost (in) dimensions. Consolidating progress in multidimensional poverty research. Innocenti Working Papers No 2014-04. UNICEF Office of Research Working Paper.

Eurostat. (2017). Children at risk of poverty or social exclusion. http://ec.europa.eu/eurostat/statistics-expla ined/index.php/Children_at_risk_of_poverty_or_social_exclusion. Accessed 24 October 2017. 
Finnäs, F. (2013). Finlandssvenskarna 2012. En statistisk rapport. Helsinki: Svenska Finlands Folkting.

Gábos, A., Lellkes, O., Platt, L., Hristova, M., \& Ward, T. (2007). Child poverty and ethnic minorities., European Commission London: Routledge.

Galloway, T. A., Gustafsson, B., Pedersen, P. J., \& Österberg, T. (2015). Immigrant child poverty-The achilles heel of the Scandinavian welfare state. In T. I. Garner \& K. S. Short (Eds.), Measurement of Poverty, Deprivation, and Economic Mobility (Vol. 23, pp. 185-219)., Research on Economic Inequality Bingley: Emerald Group Publishing Limited.

Gornick, J. C., \& Jäntti, M. (2011). Child poverty in comparative perspective: Assessing the role of family structure and parental education and employment. LIS Working Paper Series, no 570.

Gornick, J. C., \& Jäntti, M. (2012). Child Poverty in cross-national perspective: Lessons from the Luxembourg Income Study. Children and Youth Services Review, 34, 558-568.

Haanpää, L., \& Roos, S. (2015). Nuoret luupin alla 2014: Teemana kuluttajuus ja taloudellinen eriarvoisuus. Lapsi- ja nuorisotutkimuskeskus CYRIn julkaisuja 1/2015. Turku: University of Turku.

Hakovirta, M., \& Kallio, J. (2016). Children's perceptions of poverty. Child Indicators Research, 9(2), 317334. https://doi.org/10.1007/s12187-015-9315-5.

Hakovirta, M., \& Rantalaiho, M. (2012). Taloudellinen eriarvoisuus lasten arjessa. Sosiaali- ja terveysturvan tutkimuksia 124. Helsinki: Kelan tutkimusosasto.

Härtull, C., \& Saarela, J. (2014). Ethno-linguistic Groups during an economic recession: Low-income earners in the 1990s' Finland. Finnish Yearbook of Population Research, 49, 87-103.

Härtull, C., \& Saarela, J. (2018). Endogamy and income in native couples: The case of Finland. International Journal of Manpower, 39(2), 205-221.

Härtull, C., Saarela, J., \& Cederström, A. (2017). Income poverty in households with children: Finland 1987-2011. Research on Finnish Society, 10(1), 43-59.

Helminen, M.-L. (2015). Suomi ja Ruotsi vastakohtapari maahanmuutossa. Tieto \& Trendit-talous- ja hyvinvointikatsaus 3/2015. Helsinki: Statistics Finland.

Heuveline, P., \& Weinshenker, M. (2008). The international child poverty gap: Does demography matter? Demography, 45(1), 173-191.

Jäntti, M. (2010). Lapsiköyhyydestä Suomessa. In U. Hämäläinen \& O. Kangas (Eds.), Perhepiirissä (pp. 62-75). Helsinki: The Social Insurance Institution.

Kalil, A., Duncan, G. J., \& Ziol-Guest, K. M. (2016). Early childhood poverty: Short and long-run consequences over the lifespan. In M. J. Shanahan, J. T. Mortimer, \& M. Kirkpatrick Johnson (Eds.), Handbook of the life course (pp. 341-354). Switzerland: Springer International Publishing.

Liang, K., \& Zeger, S. L. (1986). Longitudinal data analysis using generalized linear models. Biometrika, $73(1), 45-51$.

Lindquist, M. J., \& Sjögren Lindquist, G. J. (2012). The dynamics of child poverty in Sweden. Population Economics, 25(4), 1423-1450.

Loikkanen, H.A., Rantala, A., \& Sullström, R. (1998). Regional income differences in Finland, 1966-96. VATT-Discussion Papers 181. Helsinki: Governmental Institute for Economic Research.

Loikkanen, H.A., Riihelä, M., \& Sullström, R. (2000). Kaupunkien, taajamien ja maaseudun väliset ja sisäiset tulo- ja kulutuserot. VATT-keskustelualoitteita 213. Helsinki: Valtion taloudellinen tutkimuskeskus.

Main, G., \& Bradshaw, J. (2016). Child poverty in the UK: Measures, prevalence and intra-household sharing. Critical Social Policy, 36(1), 38-61.

McRae, K. (1999). Conflict and compromise in multilingual societies: Finland. Helsinki: Finnish Academy of Science and Letters.

Ministry of Education and Culture. (2017). Lagändring som möjliggör frivilliga studier i det andra inhemska språket skickas ut på remiss. http://minedu.fi/artikkeli/-/asset_publisher/toisen-kotimaisen-kiele n-vapaaehtoisen-opiskelun-mahdollistava-lakimuutos-lausunnoille?_101_INSTANCE_0R8wCyp3oe bu_languageId=sv_SE. Accessed 5 October 2017.

Minujin, A., Delamonica, E., Davidziuk, A., \& Gonzales, E. D. (2006). The definition of child poverty: A discussion of concepts and measurements. Environment and urbanization, 18(2), 481-500.

Mood, C., \& Jonsson, J. O. (2016). Trends in child poverty in Sweden: Parental and child reports. Child Indicators Research, 9(3), 825-854.

Munzi, T., \& Smeeding, T. (2006). Conditions of social vulnerability, work and low income, evidence for Spain in comparative perspective. LIS Working Paper Series 448.

Natali, L., Handa, S., Chzhen, Y., Martorano, B. (with Bitler, M., Hoynes, H., \& Kuka, E.). (2014). Changes in child poverty in the OECD/EU during the great recession: An initial view. Innocenti Working Paper No 2014-16. UNICEF Office of Research Working Paper.

O’Leary, R., \& Finnäs, F. (2002). Education, social integration and minority-majority group intermarriage. Sociology, 36(2), 235-254. 
OECD. (2017). OECD Family database: Indicators. http://www.oecd.org/els/family/database.htm. Accessed 19 August 2017.

Ottosen, M. H., \& Skov, P. R. (2013). Fattigdom blandt born fodt i 1995. Dansk Sociologi, 24(1), 71-94.

Platt, L. (2009). Ethnicity and child poverty. Research Report No 576. Department for Work and Pensions, London.

Riihelä, M., \& Suoniemi, I. (2015). Tuloliikkuvuus ja köyhyyden pysyvyys. In: Taimio, H. (Ed.). Hyvinvointivaltio 2010-luvulla-mitä kello on lyönyt? (pp. 170-188). Palkansaajien tutkimuslaitos Raportteja 30 , Helsinki.

Saarela, J. (2002). Språkgruppsskillnader i utkomststödstagande. Ekonomiska Samfundets Tidskrift, 55(2), 89-97.

Saarela, J. (2004). De förmögna finlandssvenskarna? Janus, 12(1), 80-96.

Saarela, J. (2006). Wealth in two ethnic groups: The role of internal migration background. Finnish Yearbook of Population Research, 42, 43-64.

Saarela, J., \& Finnäs, F. (2003). Social background and education of Swedish and Finnish speakers in Finland. European Journal of Education, 38(4), 445-456.

Saarela, J., \& Finnäs, F. (2004). Interethnic wage variation in the Helsinki area. Finnish Economic Papers, $17(1), 35-48$.

Saarela, J., \& Finnäs, F. (2006). Can the low unemployment rate of Swedish speakers in Finland be attributed to structural factors? Journal of Socio-Economics, 35(3), 498-513.

Saarela, J., \& Finnäs, F. (2010). Mortality variation by birth region and ethnicity: An illustration based on the Finnish population register. Human Biology, 82(1), 1-15.

Saarela, J., \& Finnäs, F. (2014). Transitions within and from First Unions: Educational effects in an extended winnowing model. Marriage \& Family Review, 50(1), 35-54.

Saarela, J., \& Finnäs, F. (2016). Ethno-linguistic exogamy and divorce: Does marital duration matter? Sociological Focus, accepted for publication.

Salmi, M., Lammi-Taskula, J., \& Sauli, H. (2014). Lapsiperheiden toimeentulo. In J. Lammi-Taskula \& S. Karvonen (Eds.), Lapsiperheiden hyvinvointi 2014 (pp. 82-105). Helsinki: National Institute for Health and Welfare.

Salmi, M., Sauli, H., \& Lammi-Taskula, J. (2009). Lapsiperheiden toimeentulo. In J. Lammi-Taskula, S. Karvonen, \& S. Ahlström (Eds.), Lapsiperheiden hyvinvointi 2009 (pp. 78-93). Helsinki: National Institute for Health and Welfare.

Salmi, M., Sauli, H., \& Lammi-Taskula, J. (2012). Lasten ja lapsiperheiden asema nyky-suomessa. In A. Söderholm \& S. Kivitie-Kallio (Eds.), Lapsen kaltoinkohtelu (pp. 22-47). Helsinki: Duodecim.

Statistics Finland. (2016). Tulonjakotilasto: Pienituloisuusindikaattoreita 1966-2016. Income distribution statistics: Indicators of low-income earning. Helsinki: Statistics Finland. http://www.stat.fi/til/ tjt/2016/01/tjt_2016_01_2018-03-02_tau_003_fi.html. Accessed 1 August 2018.

Townsend, P. (1979). Poverty in the United Kingdom. London: Allen Lane and Penguin Books.

Wang, M. (2014). Generalized estimating equations in longitudinal data analysis: A review and recent developments. Advances in Statistics. https://doi.org/10.1155/2014/303728.

Whiteford, P., \& Adema, W. (2007). What works best in reducing child poverty: A benefit or work strategy? OECD Social Employment and Migration Working Papers, no 51.

Yle. (2015). Swedish remains obligatory in Finnish schools. News document. http://yle.fi/uutiset/osasto/ news/swedish_remains_obligatory_in_finnish_schools/7850431. Accessed 5 October 2017.

Zeger, S. L., \& Liang, K. (1986). Longitudinal data analysis for discrete and continuous outcomes. Biometrics, 42(1), 121-130. 